\title{
PENGARUH VIDEO PEMBELAJARAN CERITA DAN LAGU TERHADAP KEMAMPUAN BERBICARA ANAK
}

\author{
Winda Dwi Putri ${ }^{1}$; Nila Fitria ${ }^{1}$ \\ ${ }^{1}$ Program Studi Pendidikan Guru Pendidikan Anak Usia Dini, Fakultas Psikologi dan Pendidikan, \\ Universitas Al Azhar Indonesia, Jalan Sisingamangaraja Kebayoran baru, Jakarta Selatan 12110 \\ Penulis untuk Korespondensi/E-mail: nilafitria@uai.ac.id
}

\begin{abstract}
Abstrak - Tujuan penelitian ini adalah untuk melihat pengaruh video pembelajaran cerita dan lagu terhadap kemampuan berbicara anak usia 4-5 tahun di PAUD Harmoni. Metode penelitian yang digunakan adalah penelitian kuantitatif dengan desain penelitian true experimental (eksperimen yang betul-betul) dengan teknik Postest Only Control Design. Sampel penelitian yaitu anak usia 4-5 tahun dengan jumlah 30 orang yang dibagi menjadi 2 kelas terdiri dari 15 anak sebagai kelompok eksperimen (video) dan 15 anak sebagai kelompok kontrol (buku cerita). Indikator kemampuan berbicara yang digunakan adalah kemampuan mengulang kembali kalimat sederhana, menjawab pertanyaan sesuai pertanyaan, dan menceritakan kembali cerita atau dongeng yang pernah didengar. Teknik pengumpulan data menggunakan tes lisan yang digunakan untuk melakukan penilaian posttest antara kelas kontrol (buku cerita) dan kelas eksperimen (video) dan dokumentasi.Hasil analisis data posttest pada nilai rata-rata (mean) kelas eksperimen (video) lebih besar dibandingkan kelas kontrol (buku cerita), yaitu sebesar 30.2667 untuk kelas eksperimen (video) dan 22.0667 untuk kelas kontrol (buku cerita). Jika dilihat dari standar deviasinya kelas eksperimen (video) lebih besar dibandingkan kelas kontrol (buku cerita) yaitu 3.12745 untuk kelas eksperimen (video) dan 2.34419 untuk kelas kontrol (buku cerita). Hal ini juga ditunjukkan dengan hasil uji Independent Sample T-test pada bagian equal variances assumed diketahui nilai Sig. (2-tailed) sebesar 0.000, menunjukkan bahwa $0.000<0.05$ maka H0 ditolak, artinya ada perbedaan yang signifikan antara nilai belajar kelas control (buku cerita) dan kelas eksperimen (video). Kesimpulannya adalah terdapat pengaruh penggunaan video pembelajaran cerita dan lagu yang dilihat dari perbedaan nilai rata-rata kelas yang diberi video pembelajaran cerita dan lagu (treatment) dengan kelas yang tidak diberi perlakuan (control).
\end{abstract}

Kata kunci: Video pembelajaran cerita dan lagu; kemampuan berbicara

Abstract - The purpose of this study was to look at the effect of video learning stories and songs on the speaking ability of children aged 4-5 years in PAUD Harmoni. The research method used is quantitative research with true experimental research designs (truly experiments) with the Postest Only Control Design technique. The research sample of children aged 4-5 years with a total of 30 people divided into 2 classes consisted of 15 children as the experimental group (video) and 15 children as a control group (story book). Indicators of speaking ability used are the ability to repeat simple sentences, answer questions according to questions, and retell stories or tales that have been heard. Data collection techniques used oral tests that were used to carry out posttest assessments between the control class (story book) and the experimental class (video) and documentation. The results of posttest data analysis on the average value (mean) of the experimental class (video) is greater than the control class (story book), which is 30.2667 for the experimental class (video) and 22.0667 for the control class (story book). If seen from the standard deviation the experimental class (video) is greater than the control class (story book), namely 3.12745 for the experimental class (video) and 2.334419 for the control class (story book). This is also shown by the results of the Independent Sample T-test on the equal variances assumed assumed the Sig. (2-tailed) of 0.000, indicating that $0.000<0.05$ then $\mathrm{HO}$ is rejected, meaning that there is a significant difference between the value of control class learning (story books) and experimental classes (video). The conclusion is that there is an influence of the use of video learning stories and songs that are seen from the difference in the average value of the class that is given a video learning stories and songs (treatment) with a class that is not treated (control). 


\section{PENDAHULUAN}

$\mathrm{P}$ endidikan merupakan salah satu modal seseorang agar mampu meraih kesuksesan dalam kehidupannya. Semua orang berhak untuk mendapatkan pendidikan sebagaimana tercantum dalam Undang-Undang Dasar 1945 Pasal 31 ayat (1) menyatakan: Setiap warga Negara berhak mendapat pendidikan. Untuk itu orang dewasa ataupun anak-anakwajib memperoleh pendidikan. Dengan diberikannya pendidikan diharapkan kelak anak Indonesia dapat tumbuh menjadi seseorang yang cerdas dengan potensi yang dimilikinya dan menjadi bangsa Indonesia yang berkualitas.Hal ini juga sesuai dengan UndangUndang RI Nomor 23 Tahun 2002 Pasal 9 Ayat 1 tentang Perlindungan Anak yang menyatakan bahwa setiap anak berhak memperoleh pendidikan dan pendidikan dalam rangka penelitian pribadinya dan tingkat kecerdasannya sesuai dengan minat dan bakatnya.

Pendidikan Anak Usia Dini dalam UndangUndang Nomor 20 Tahun 2003 tentang Sistem Pendidikan Nasional adalah suatu upaya pembinaan yang ditujukan kepada anak sejak lahir sampai usia enam tahun yang dilakukan melalui pemberian rangsangan pendidikan untuk membantu pertumbuhan dan perkembangan jasmani dan rohani agar anak memiliki kesiapan dalam memasuki pendidikan lebih lanjut. Hadirnya Pendidikan Anak Usia Dini (PAUD) memberikan daya tarik perhatian masyarakat untuk menaungi dan memberikan pendidikan bagi anak usia dini.

PAUD memegang peranan penting dalam pendidikan anak. Pendidikan yang diberikan oleh guru dengan kurikulum yang jelas serta adanya berbagai media pembelajaran yang disesuaikan dengan karakteristik anak didik sebagai langkah awal untuk membentuk dan menanamkan nilai moral karakter anak. Anak usia dini memiliki kemampuan belajar yang luar biasa, khususnya pada masa anak-anak awal. Keinginan anak untuk belajar menjadikan ia aktif dan eksploratif. Anak dengan seluruh panca inderanya dapat memahami sesuatu dan dalam waktu singkat ia akan beralih ke hal lain untuk dipelajari.Anak usia dini memiliki 6 aspek perkembangan, salah satunya perkembangan bahasa. Pengertian bahasa yang dikemukakan oleh Badudu (dalam Gunarti, 2008) yang menyatakan bahasa adalah alat penghubung atau komunikasi antar anggota masyarakat yang terdiri dari individu-individu yang menyatakan pikiran, perasaan dan keinginannya.

Anak usia dini berada dalam masa perkembangan kecerdasan dan bahasa yang sangat pesat. Mereka memiliki kapasitas besar untuk belajar kata-kata dan menyukai tantangan mempelajari kata-kata baru. Ini menjelaskan kecintaan anak usia dini akan kata-kata besar dan kemampuan mereka untuk mengatakan dan menggunakannya (Morrison, 2012).

Salah satu lingkup perkembangan bahasa yang tertuang didalam Peraturan Menteri Pendidikan dan Kebudayaan RI Nomor 137 Tahun 2013 adalah kemampuan mengungkapkan bahasa. Kemampuan mengungkapkan bahasa juga mempengaruhi kemampuan berbicara pada anak karena dengan mengungkapkan bahasa anak dapat melatih kemampuan berbicaranya seperti mengulang kembali kalimat sederhana, menjawab pertanyaan sesuai pertanyaan, dan menceritakan kembali cerita atau dongeng yang pernah didengar. Kemampuan mengungkapkan bahasa menjadi penting karena dengan berbahasa anak akan mampu mengutarakan keinginannya dan dapat berkomunikasi dengan orang lain disekitarnya. Bahasa merupakan hal penting yang dapat mengekspresikan pikiran dan pengetahuan bila anak mengadakan interkasi dengan orang lain. Anak-anak yang sedang tumbuh dan berkembang, mengkomunikasikan kebutuhan pikiran dan perasaannya melalui bahasa dengan kata-kata yang mempunyai makna, oleh sebab itu kemampuan berbahasa anak harus distimulasi sejak dini.

Metode yang dapat dilakukan untuk menstimulasi perkembangan bahasa anak diantaranya dengan bercerita, bernyanyi, tanya jawab, dan mendongeng. Metode tersebut dapat melatih anak untuk memahami bahasa sehingga anak dapat terstimulasi untuk mengungkapkan bahasanya sendiri. Hal ini serupa dengan pernyataan Lev Vygotsky yang meyakini bahwa perkembangan mental, bahasa, dan sosial di dukung dan ditingkatkan oleh orang lain lewat interaksi sosial (Morrison, 2012). 
Menstimulasi perkembangan bahasa dapat di lakukan dengan berbagai media. Menurut Gerlach dan Ely (1971) media dalam bahasa arab adalah perantara atau pembawa pesan dari pengirim kepada penerima pesan (Sadiman, dkk, 2011). Media pendukung tersebut seperti buku, buku cerita bergambar, big book, hand puppet, dan juga gadget. Seiring perkembangan zaman, anak usia dini sudah mulai sering berinteraksi dengan gadget. Hampir setiap individu mulai dari anak-anak hingga orang dewasa kini menggunakan gadget. Penggunaan gadget pada anak dapat berpengaruh baik maupun buruk. Pengaruh baik penggunaan gadget untuk anak dapat dimanfaatkan sebagai media edukasi baik berupa permainan atau video menarik. Namun penggunaan gadget secara berlebihan akan berdampak buruk bagi pola perilaku anak dalam kesehariannya, anakanak yang cenderung terus menerus menggunakan gadget akan bergantung dan menjadikan gadget sebagai kegiatan yang harus dan rutin dilakukan dalam aktifitas sehari-hari.

Pemanfaatan gadget yang dapat dilakukan oleh orang dewasa salah satunya dengan menggunakan video pembelajaran. Video pembelajaran memiliki banyak informasi berupa teks, suara, dan gambar bergerak sehingga dapat menarik perhatian anak. Video termasuk dalam kategori bahan ajar audiovisual atau bahan ajar pandang dengar. Bahan ajar audio visual merupakan bahan ajar yang mengombinasikan dua materi, yaitu materi visual dan materi auditif. Materi auditif ditujukan untuk merangsang indra pendengaran sedangkan materi visual untuk merangsang indra penglihatan. Dengan kombinasi dua materi ini, pendidik dapat menciptakan proses pembelajaran yang lebih berkualitas, karena komunikasi berlangsung secara lebih efektif (Prastowo, 2011).

\section{Kemampuan Berbicara Anak Usia 4-5 Tahun.}

Yusuf (2000) mengemukakan sebuah pendapat bahwa berbicara merupakan salah satu keterampilan dalam perkembangan bahasa. Seseorang dapat saling berkomunikasi dan saling bertukar informasi kepada orang lain melalui berbicara. Berbicara adalah mengucapkan suara yang berarti dan menyampaikannya kepada orang lain tanpa perantara suara itu. Salah satu keterampilan yang sangat penting dimiliki bagi seseorang adalah keterampilan berbicara karena dengan berbicara seseorang dapat saling bertukar informasi, dan dapat menyampaikan keinginannya kepada orang lain. Misalnya, seseorang dapat berkomunikasi secara langsung dengan bertatap muka. Yusuf menjelaskan bahwa berbicara adalah syarat agar terjadinya komunikasi. Pendapat yang sama juga dijelaskan oleh Haryadi dan Zamzani dalam Suhartono (2005) yang menjelaskan berbicara merupakan suatu proses berkomunikasi, sebab di dalamnya terjadi pesan dari suatu sumber ke sumber lainnya. Suatu pesan dapat tersampaikan melalui komunikasi. Aktivitas serta penyampaian informasi, baik itu pesan, ide, dan gagasan, dari satu pihak ke pihak lainnya dilakukan seseorang dengan komunikasi baik secara verbal atau lisan sehingga memudahkan kedua belah pihak untuk saling mengerti dengan tujuan untuk memberikan pengetahuan kepada orang lain.

Samosir (2009) menyatakan bahwa "speaking skills were the capacity to reveal the opinion or thoughts and the feeling to someone or the group in an oral manner, good face to face or with the long distance", yang artinya kemampuan berbicara adalah kemampuan mengungkapkan pendapat atau pikiran dan perasaan kepada seseorang atau kelompok secara lisan, baik secara berhadapan ataupun jarak jauh. Kemampuan berbicara yaitu berasal dari dalam diri seseorang yang berhubungan atau berkaitan dengan tujuan untuk mengutarakan pikiran dalam bentuk pendapat dan perasaan kepada orang lain. Berbicara juga bias dalam bentuk berhadapan ataupun jarak jauh. Contohnya berbicara secara berhadapan yaitu kita dapat bertatap muka atau bertemu dengan orang lain menyampaikan pendapat dan pikiran kita kepada orang lain. Sedangkan berbicara secara jarak jauh yaitu dengan cara menelfon, video call, atau mengirim surat. Kemampuan berbicara juga lebih diperjelas oleh Akhadiah (2012) yang menjelaskan bahwa kemampuan berbicara meliputi pelafalan bunyi, penampilan tekanan, nada, jangka intonasi dan ritme, penggunaan kata dan kalimat, dan aspek kebahasaan yang mencakup kenyaringan, kelancaran, sikap bicara, gerak-gerik, mimik muka, penalaran dan santun berbicara. Kemampuan berbicara berhubungan dengan adanya fungsi-fungsi anggota tubuh sehingga dapat mengeluarkan bunyi, tekanan, nada, 
intonasi, ritme dan lainnya yang nantinya bisa terlihat dari kelancaran anak untuk menyampaikan pendapat.

Kemampuan berbicara anak meningkat bermula dari gerakan dan tanda isyarat untuk menunjukkan keinginannya secara bertahap dan berkembang menjadi suatu komunitas yang tepat dan jelas. Sujiono (2013) mengatakan anak mampu mengembangkan kemampuan berbahasa dengan cepat, mereka seringkali terlihat berbicara sendiri dengan suara keras ketika mereka memecahkan masalah atau menyelesaikan suatu kegiatan.

Lebih lanjut Sujiono (2013) menjelaskan beberapa aspek kemampuan berbicara yang dikembangkan pada anak usia 4-5 tahun adalah sebagai berikut:
a. Dapat berbicara dengan menggunakan kalimat sederhana yang terdiri dari 4-5 kata.

b. Mampu melaksanakan tiga perintah lisan secara berurutan dengan benar.

c. Senang mendengarkan dan menceritakan kembali cerita sederhana dengan urut dan mudah dipahami.

d. Menyebutkan nama, jenis kelamin dan umurnya.

e. Menyebut nama panggilan orang lain (teman, kakak, adik, atau saudara yang telah dikenalnya)

f. Mengerti bentuk pertanyaan dengan menggunakan apa, mengapa, dan bagaimana.

g. Dapat menggunakan kata depan: di dalam, di luar, di atas, di bawah, di samping.

h. Dapat mengulang lagu anak-anak dan menyanyikan lagu sederhana.

i. Dapat menjawab telepon dan menyampaikan pesan sederhana.

j. Dapat berperan serta dalam suatu percakapan dan tidak mendominasi untuk selalu ingin didengar.

\section{Media Pembelajaran}

Penggunaan media dalam proses pembelajaran bertujuan untuk memaksimalkan pencapaian perkembangan kemampuan berbicara anak. Media yang digunakan dalam sebuah proses pembelajaran disebut sebagai media pembelajaran. Menurut Association of Education and Communication Technology
(AECT) 1997, media atau bahan lunak (software) adalah sumber belajar yang berisi pesan atau informasi pendidikan yang biasanya disajikan dengan mempergunakan peralatan (Sadiman, 2011). Media pembelajaran adalah berupa alat yang dapat digunakan guru untuk melakukan proses pembelajaran yang berisi pesan atau informasi yang akan membantu siswa memahami materi pembelajaran. Media tersebut bias berupa buku, video, ataupun peralatan lainnya yang mana media tersebut terdapat pesan ataupun informasi pendidikan.

Sedangkan, menurut Hamalik (dalam Darwanto, 2007) mengemukakan bahwa media pendidikan adalah "alat" metode, teknik yang digunakan dalam rangka untuk lebih mengefektifkan komunikasi dan interaksi antara guru dengan murid dalam proses pendidikan dan pengajaran. Pendapat yang sama juga menjelaskan bahwa media adalah alat yang dapat membantu proses belajar mengajar dan berfungsi untuk memperjelas makna pesan yang disampaikan sehingga dapat mencapai tujuan pembelajaran dengan lebih baik dan sempurna (Kustandi \& Sutjipto, 2011). Pengertian yang diungkapkan Kustandi dan Sutjipto sama halnya dengan yang diungkapkan oleh Darwanto dalam Hamalik, intinya bahwa segala sesuatu baik berupa metode, alat, dan teknik yang digunakan guru dalam belajar demi tercapainya keefektifan pembelajaran disebut media. Media apa saja bisa digunakan oleh guru untuk memberikan materi pembelajaran kepada siswa.

Proses pembelajaran dapat dibantu oleh media pembelajaran. Media adalah salah satu alat yang dapat memudahkan proses pembelajaran. Media pembelajaran dapat memudahkan guru untuk memberikan materi kepada siswa, berbagai jenis media yang dapat digunakan juga sesuai dengan kebutuhannya. Media pembelajaran terdiri dari beberapa jenis, berikut jenis media pembelajaran menurut Sadiman (2008) Terdapat berbagai jenis media belajar, diantaranya :

a. Media Visual, adalah media yang hanya melibatkan indera penglihatan. Terdapat dua jenis pesan yang dibuat dalam media visual, yakni pesan verbal dan non verbal. Jenis media visual adalah grafik, diagram, chart, bagan, poster, komik

b. Media Audial. Media Audial berkaitan dengan indera pendengar, di mana pesan 
yang disampaikan dituangkan dalam lambang-lambang auditif, baik verbal (ke dalam kata-kata maupun bahasa lisan) maupun non verbal. Ada jenis media yang dapat dikelompokkan dalam media audio ini antara lain, radio, tape recorder, laboratorium bahasa, dan sejenisnya

c. Projected still media (Media Visual Dua Dimesi) merupakan media yang bersifat elektronik yang diproyeksikan dan terdiri dari perangkat keras (hardware) dan perangkat lunak (software). Jenis media yang dapat dikelompokkan dalam media ini antara lain slide, over head projector $(O H P)$, in focus dan sejenisnya.

d. Projected motion media (Media Audio Visual Gerak) adalah media yang dapat menampilkan unsur suara dan gambar yang bergerak jenis media ini antara lain film, televisi, video (VCD dan DVD), komputer dan lain-lain

Media pembelajaran adalah alat yang digunakan untuk mencapai tujuan pembelajaran yang di dalam nya terdapat sebuah pesan dan informasi yang akan memberikan keefektifan dalam melakukan pembelajaran, sehingga siswa akan lebih mudah menerima materi yang diberikan. Berbagai jenis media pembelajaran yang dapat membantu dan memudahkan guru untuk mengembangkan keterampilan berbicara anak adalah media audio visual gerak atau projected motion media karena media ini menampilkan unsur suara, serta gambar yang bergerak.

\section{Video Pembelajaran}

Media pembelajaran video adalah salah satu media yang dapat digunakan sebagai media pembelajaran. Video pembelajaran dapat digunakan guru sebagai media pembelajaran karena pada video terdapat gambar bergerak yang dapat menarik perhatian anak. Hal ini terkait dengan pernyataan Daryanto (2010) video merupakan suatu medium yang sangat efektif untuk membantu proses pembelajaran, baik untuk pembelajaran massal, individual, maupun berkelompok. Media video adalah segala sesuatu yang memungkinkan sinyal audio dapat dikombinasikan dengan gambar bergerak secara sekuensial. Materi yang memerlukan visualisasi yang mendemonstrasikan hal-hal seperti gerakan motorik tertentu, ekspresi wajah, maupun suasan lingkungan tertentu maka penyampaian materi akan lebih baik apabila disajikan melalui teknologi video.

Video dapat menggambarkan suatu objek yang bergerak bersama-sama dengan suara alamiah atau suara yang sesuai. Kemampuan video melukiskan gambar hidup dan suara memberikan daya tarik tersendiri. Video menyajikan informasi, memaparkan proses, menjelaskan konsep-konsep yang rumit, mengajarkan keterampilan, menyingkat atau memperpanjang waktu, dan mempengaruhi sikap. Sehingga siswa merasa seperti berada di suatu tempat yang sama dengan program yang ditayangkan video (Kustandi \& Sutjipto, 2011). Video dapat memberikan daya tarik kepada siswa karena di dalam nya video memberikan berbagai macam informasi baik informasi pendidikan maupun yang lainnya. Contohnya pembelajaran untuk anak usia dini video yang berisi cerita akan lebih menarik untuk anak dibandingkan dengan hanya mendengarkan gurunya bercerita dengan buku cerita karena video menggambarkan suatu gambar hidup dan juga didalamnya terdapat suara yang akan menarik perhatiannya.

Sedangkan menurut Sadiman (2011) video sebagai media audio-visual yang menampilkan gerak, semakin lama semakin populer dalam masyarakat kita. Pesan yang disajikan bisa berupa fakta (kejadian/peristiwa penting, berita) maupun fiktif (misalnya cerita), bisa bersifat informatif, edukatif maupun instruksional. Video adalah sebuah media yang dapat memuat sebuah gambar yang menampilkan gerak saat video di putar. Dalam video terdapat sebuah pesan yang dapat disampaikan berupa pesan informasi, secara fakta ataupun fiktif. Fakta pada video biasanya berupa peristiwa penting atau berita mengenai suatu kejadian, sedangkan fiktif pada video adalah berupa suatu cerita yang sengaja dibuat untuk memberikan pesan pembelajaran maupun hiburan.

Penggunaan media pembelajaran harus diperhatikan guru saat memberikannya pada anak. Penggunaan media yang benar akan membantu anak memahami apa yang telah disampaikan. Beberapa hal yang harus diperhatikan dalam penggunaan video dalam pembelajaran, Usman (2002) menjelaskan sebagai berikut: 
a. Guru harus mempersiapkan unit pelajaran terlebih dahulu, kemudian baru memilih video yang tepat untuk mencapai tujuan pengajaran yang diharapkan.

b. Guru juga harus mengetahui durasi video, dimana video tersebut harus disesuaikan dengan jam pelajaran.

c. Mempersiapkan kelas, yang meliputi persiapan siswa dengan memberikan penjelasan global tentang isi video yang akan diputar dan persiapan peralatan yang akan digunakan demi kelancaran pembelajaran

d. Aktivitas lanjutan, setelah pemutaran video selesai, sebaiknya guru melakukan refleksi dan tanya jawab dengan siswa untuk mengetahui sejauh mana pemahaman siswa terhadap materi tersebut.

Kelebihan video menurut Daryanto (2010), sebagai berikut :

a. Ukuran tampilan video sangat fleksibel dan dapat diatur sesuai dengan kebutuhan.

b. Video merupakan bahan ajar non cetak yang kaya informasi dan lugas karena dapat sampai ke hadapan siswa secara langsung.

c. Video menambah suatu dimensi baru terhadap pembelajaran.

Adapun tujuan dari penelitian ini adalah untuk mengetahui adakah pengaruh video pembelajaran cerita dan lagu terhadap kemampuan berbicara anak usia 4-5 tahun di PAUD Harmoni.

\section{METODE PENELITIAN}

Penelitian ini dilaksanakan di PAUD Harmoni, Jalan Petukangan Selatan RW 010 RT 010, Jakarta Selatan. Metode penelitian yang digunakan dalam penelitian ini adalah metode penelitian eksperimen. Metode penelitian eksperimen merupakan penelitian yang digunakan untuk mencari pengaruh perlakuan tertentu terhadap yang lain dalam kondisi yang terkendalikan (Sugiyono, 2018). Tujuan penelitian eksperimen ini untuk menguji satu variabel atau lebih terhadap variabel lain. Variabel yang dapat dikontrol atau dimanipulasi oleh peneliti yaitu variabel bebas (Independent Variable), sedangkan variabel yang dipengaruhi oleh variabel bebas disebut dengan variabel terikat (Dependent Variable). Penelitian eksperimen bertujuan untuk mengungkapkan hubungan sebab akibat dengan cara melibatkan kelompok kontrol disamping kelompok eksperimental, serta untuk mengetahui sejauh mana pengaruh video pembelajaran cerita dan lagu terhadap kemampuan berbicara anak usia 4-5 tahun, yang berjumlah 30 anak yang dibagi menjadi 15 anak.

Teknik Pengumpulan Data menggunakan tes lisan, yang merupakan sebuah instrumen atau prosedur yang sistematis untuk mengukur suatu sampel tingkah laku (Nurgiyantoro, 2010). Penggunaan tes dimaksudkan untuk mengukur kemampuan berbicara anak dalam lingkup mengungkapkan bahasa seperti mengulang kembali kalimat sederhana, menjawab pertanyaan sesuai pertanyaan, dan menceritakan kembali cerita atau dongeng yang pernah di dengar. Penelitian ini menggunakan tes lisan di kelas. Nurgiyantoro (2010) menjelaskan bahwa tes lisan di kelas dimaksudkan sebagai tes yang dilakukan bersamaan dengan kegiatan pembelajaran. Bentuk tes lisan ini bisa berupa kuis, pertanyaan singkat, atau menjawab latihan yang sengaja diberikan.

Pada penelitian ini peneliti akan mendokumentasikan kegiatan belajar di kelas baik di kelas yang diberikan treatment dengan menggunakan video pembelajaran maupun kelas kontrol yang tidak menggunakan video pembelajaran.

Pada instrumen kemampuan berbicara anak akan diambil nilai pada kemampuan berbicara sesuai dengan indikator yang ditentukan yaitu mengulang kalimat sederhana, menjawab pertanyaan sesuai pertanyaan, dan menceritakan kembali cerita atau dongeng yang pernah di dengar. Penilaian tersebut dapat dilihat menggunakan rubrik penilaian dengan keterangan skor penilaian sebagai berikut:

$\begin{array}{ll}\text { Keterangan Skor Penilaian } & : 1 \\ \text { BB (Belum Berkembang } & : 2 \\ \text { MB (Mulai Berkembang) } & : 3 \\ \text { BSH (Berkembang Sesuai Harapan) } & : 4 \\ \text { BSB (Berkembang Sangat Baik) } & \end{array}$

\section{Validitas Video Pembelajaran cerita dan lagu}

Validasi ahli atau (expert judgement) pada instrumen video pembelajaran dilakukan dengan meminta beberapa orang ahli dalam bidangnya untuk menilai video pembelajaran yang akan diberikan kepada anak sebagai 
pengaruh terhadap kemampuan berbicara anak usia 4-5 tahun. Penilaian pada video pembelajaran terdiri dari penilian konten video, tampilan dan penyajian. Penilaian tersebut akan dilakukan dengan meminta bantuan kepada dosen program studi PG.PAUD, Ilmu Komunikasi, dan Guru untuk memvalidasi konten video dan tampilan video. Para ahli dapat menilai video berdasarkan skor yang sudah ditentukan, berikut adalah skor penilaian video.

Keterangan Skor :

$\begin{array}{ll}\text { STS (Sangat Tidak Sesuai) } & : 1 \\ \text { TS (Tidak Sesuai) } & : 2 \\ \text { S (Sesuai) } & : 3 \\ \text { SS (Sangat Sesuai) } & : 4\end{array}$

Penilaian video 1 yang dinilai oleh validator expert judgement di atas dapat kita simpulkan bahwa rata-rata keseluruhan responden menjawab setiap pertanyaan. Sedangkan modus, kebanyakan responden memberikan penilaian dengan nilai 3 dimana nilai ini masuk dalam kategori sesuai. Standard deviasi expert video 1 sebesar 0.23 , dimana nilai standart deviasinya 0.23 < rata-rata 3.13 artinya bahwa tidak terjadi kesenjangan tinggi atau datanya stabil.

Penilaian video 2 yang dinilai oleh validator expert judgement di atas dapat kita simpulkan bahwa rata-rata keseluruhan responden menjawab setiap pertanyaan. Sedangkan modus, kebanyakan responden memberikan penilaian dengan nilai 3 dimana nilai ini masuk dalam kategori sesuai. Standard deviasi expert video 1 sebesar 0.25 , dimana nilai standart deviasinya 0.25 < rata-rata 3.19 artinya bahwa tidak terjadi kesenjangan yang tinggi atau datanya stabil.

\section{Validitas Kemampuan Kognitif Anak Usia 4- 5 Tahun}

Uji validitas variabel penelitian merupakan prosedur awal agar data yang diperoleh layak untuk pengujian lebih lanjut. Uji validitas instrumen menggunakan rumus Korelasi Product Moment. Menurut Sugiyono (2018) rumusnya sebagai berikut:

$$
r_{x y}=\frac{n \sum x y_{-\left(\sum x\right)}\left(\sum y\right)}{\sqrt{\left(n \Sigma x^{2}-\left(\sum x\right)^{2}\left(n \Sigma y^{2}-(\Sigma y)^{2)}\right.\right.}}
$$

Penelitian ini menggunakan uji coba terhadap 30 responden untuk mendapatkan hasil uji kelayakan. Hasil pengujian dapat dilihat pada tabel berikut.

\section{Realibilitas Variabel Kemampuan Berbicara Anak Usia 4-5 Tahun}

Reliabilitas suatu test merujuk pada derajat stabilitas, konsistensi, daya prediksi, dan akurasi. Pengukuran yang memiliki reliabilitas yang tinggi adalah pengukuran yang dapat menghasilkan data yang reliabel. Untuk mengukur reliabilitas instrument digunakan rumus Alpha Cronbach, yaitu:

$$
r_{11}=\frac{k}{k-1} \times\left\{1-\frac{\sum S_{i}}{S_{t}}\right\}
$$

Jika nilai alpha $>0.6$ artinya reliabilitas mencukupi (sufficient reliability) sementara jika alpha > 0.80 ini mensugestikan seluruh item reliabel dan seluruh tes secara konsisten memiliki reliabilitas yang kuat.

Tabel 1. Hasil Uji Reliabilitas

Reliability Statistics

\begin{tabular}{|r|r|}
\hline $\begin{array}{c}\text { Cronbach's } \\
\text { Alpha }\end{array}$ & N of Items \\
\hline .741 & 3 \\
\hline
\end{tabular}

Tabel tersebut menunjukkan bahwa nilai Alpha Cronbach's 0,741 > 0,06, hal ini menunjukkan bawah item pertanyaan yang digunakan dalam penilitian ini lulus uji reliabel.

Teknik analisis data dalam penelitian kuantitif menggunakan statistik (Sugiyono, 2018) Teknik analisa data yang akan di pakai adalah Uji Independent Sample T-test.

\section{HASIL DAN PEMBAHASAN}

Penelitian ini dilakukan di Lembaga Pendidikan Anak Usia Dini yaitu PAUD Harmoni yang berlokasi di Jalan Petukangan Selatan RW 010 RT 010, Jakarta Selatan. PAUD Harmoni adalah lembaga pendidikan yang memberikan layanan pendidikan untuk anak usia dini mulai dari usia 3-6 tahun dengan jumlah guru 
sebanyak 6 orang. Penelitian ini hanya mengambil 30 anak yang berusia 4-5 tahun. Penelitian ini dilakukan selama 4 kali, yaitu pada tanggal 16, 18, 30 Oktober dan 1 November 2019.

Deskriptif data adalah upaya menampilkan data agar data tersebut dapat dipaparkan secara baik dan diinterpretasikan secara mudah. Deskripsi data meliputi penyusunan data dalam bentuk tampilan yang mudah terbaca secara lengkap. Penyajian data dalam deskripsi data digunakan tabe frekuensi dan menampilkannya secara visual dengan histrogram.

\section{Deskriptif Hasil Penilaian Anak Kelas Eksperimen (Video)}

Diketahui bahwa frekuensi nilai terendah sampai frekuensi nilai tertinggi pada kelas eksperimen (video). Pada indikator pertama nilai tertinggi yaitu sebesar 15 dan nilai terendah adalah 8. Siswa dengan nilai tertinggi pada indikator pertama lebih unggul pada kemampuan mengulang kalimat sederhana. Indikator kedua nilai tertinggi sebesar 12 dan nilai terendah yaitu 8 . Nilai tertinggi pada indikator kedua siswa lebih unggul dalam kemampuan nya menjawab pertanyaan sesuai pertanyaan dibandingkan dengan siswa yang memiliki nilai terendah. Sedangkan untuk indikator ketiga nilai tertinggi sebesar 12 dan terendah 8 . Siswa yang memiliki nilai tertinggi lebih unggul dalam kemampuan nya untuk menceritakan kembali cerita atau dongeng yang pernah didengar. Berikut adalah grafik frekuensi nilai kelas eksperimen (video) berdasarkan hasil dari jumlah ketiga indikator.

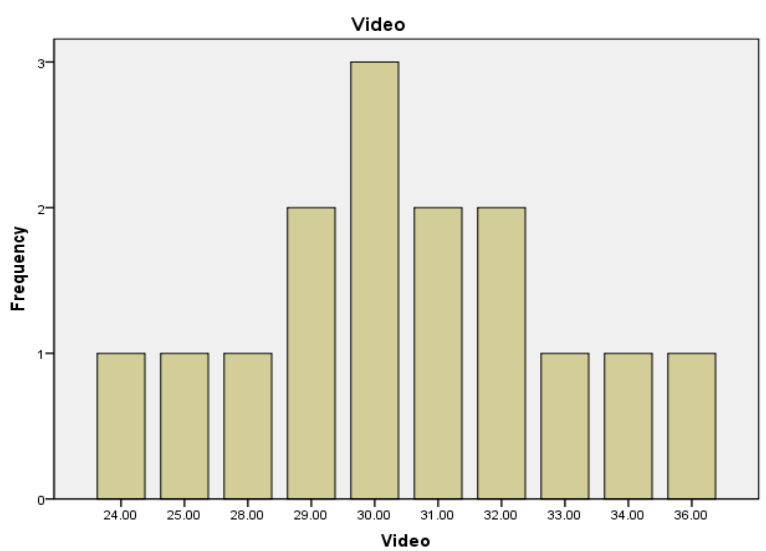

Gambar 1. frekuensi nilai pada kelas eksperimen (video)

\section{Deskriptif Hasil Penilaian Anak Kelas Kontrol (Buku Cerita)}

Diketahui bahwa frekuensi nilai terendah sampai frekuensi nilai tertinggi pada kelas kontrol (buku cerita). Pada indikator pertama nilai tertinggi yaitu 10 dan nilai terendah yaitu 4. Siswa dengan nilai tertinggi pada indikator pertama lebih unggul pada kemampuan mengulang kalimat sederhana. Indikator kedua nilai tertinggi sebesar 9 dan nilai terendah yaitu 5. Nilai tertinggi pada indikator kedua siswa lebih unggul dalam kemampuan nya menjawab pertanyaan sesuai pertanyaan dibandingkan dengan siswa yang memiliki nilai terendah. Sedangkan untuk indikator ketiga nilai tertinggi sebesar 9 dan terendah 4 . Siswa yang memiliki nilai tertinggi lebih unggul dalam kemampuan nya untuk menceritakan kembali cerita atau dongeng yang pernah didengar. Berikut adalah grafik frekuensi nilai kelas kontrol (buku cerita) berdasarkan hasil dari jumlah ketiga indikator.

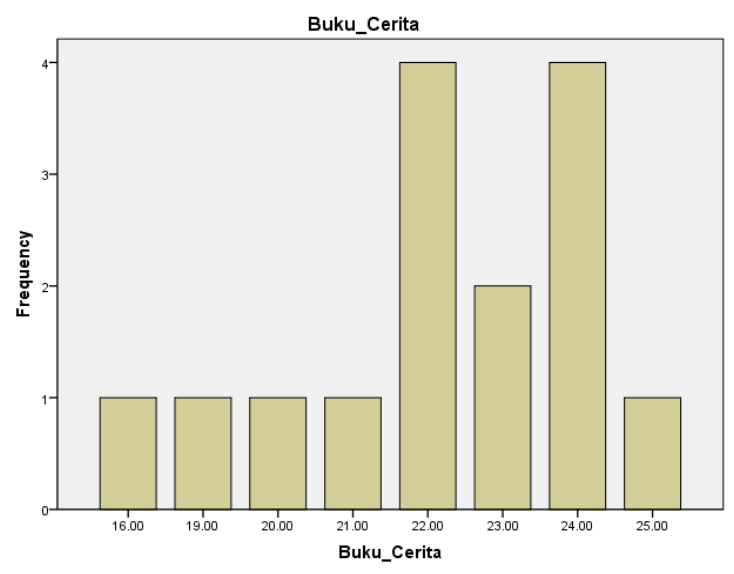

Gambar 2. frekuensi nilai pada kelas kontrol (buku cerita)

Dari data frekuensi ini juga dapat dihitung ratarata hasil belajar untuk mengetahui kategorinya (minimum, maximum, dan mean). Adapun ratarata siswa kelas eksperimen (video) dan kelas kontrol (buku cerita) dihitung dengan perhitungan statistik menggunakan bantuan SPSS 20 adalah sebagai berikut. 
Tabel 2. Descriptive Statistics

\section{Descriptive Statistics}

\begin{tabular}{|l|r|r|r|r|r|}
\hline & $\mathrm{N}$ & Minimum & Maximum & Mean & Deviation \\
\hline Video & 15 & 24.00 & 36.00 & 30.2667 & 3.12745 \\
Buku_Cerita & 15 & 16.00 & 25.00 & 22.0667 & 2.34419 \\
Valid N & 15 & & & & \\
(listwise) & & & & & \\
\hline
\end{tabular}

Dari Tabel 2. di atas dapat dilihat bahwa nilai minimum kelas eksperimen (video) sebesar 24.00 dan nilai maximum sebesar 36.00. sedangkan nilai minimum untuk kelas kontrol (buku cerita) sebesar 16.00 dan nilai maximum sebesar 25.00. Dapat dilihat bahwa nilai ratarata (mean) kelas eksperimen (video) lebih besar dibandingkan kelas kontrol (buku cerita), yaitu sebesar 30.2667 untuk kelas eksperimen (video) dan 22.0667 untuk kelas kontrol (buku cerita). Jika dilihat dari standar deviasinya kelas eksperimen (video) lebih besar dibandingkan kelas kontrol (buku cerita) yaitu 3.12745 untuk kelas eksperimen (video) dan 2.34419 untuk kelas kontrol (buku cerita).

\section{Uji Hipotesis}

Analisis untuk menguji hipotesis data yang digunakan dalam penelitian ini adalah dengan menggunakan uji normalitas, uji homogentitas, dan uji beda dengan menggunakan independent sampel t-test. Sebelum dilakukan analisis maka harus dilakukan dahulu uji prasyarat apakah data tersebut dapat dianalisis dengan menggunakan independent sample t-test. Jika uji prasyarat (uji normalitas dan uji homogenitas) memenuhi maka selanjutnya dapat dilakukan analisis dengan uji independen sample t-test.

\section{Uji Normalitas}

Uji normalitas digunakan untuk mengetahui data yang diperoleh dari hasil penelitian berdistribusi normal atau tidak. Suatu data dikatakan berdistribusi normal apabila taraf signifikansinya $\geq 0.05$, sedangkan jika taraf signifikansinya $<0.05$ maka data tersebut dikatakan tidak berdistribusi normal. Uji normalitas dapat dilakukan dengan berbagai cara. Dalam uji normalitas data, jika data berdistribusi normal maka akan dianalisis dengan uji statistik parametrik. Sedangkan apabila data tidak berdistribusi normal maka akan dianalisis dengan uji statistik non parametrik. Uji normalitas ini menggunakan bantuan SPSS 16.0 for windows dengan teknik Kolmogorov Smirnov-Z..Berikut ini hasil uji normalitas dengan Kolmogorov Smirnov-Z.

Dari hasil perhitungan uji normalitas untuk kelas eksperimen (video) diperoleh nilai $Z$ yaitu 0.553 dan Asymp.Sign sebesar 0.920. Karena nilai $\mathrm{Z}$ dan Asymp.Sign $\geq 0.05$ maka dapat disimpulkan bahwa data rata-rata pada kelas eksperimen (video) berdistribusi normal. Sedangkan uji normalitas pada kelas control (buku cerita) diperoleh nilai $\mathrm{Z}$ yaitu 0.860 dan Asymp.Sign 0.451 maka dapat disimpulkan bahwa data rata-rata pada kelas control (buku cerita) juga berdistribusi normal.

\section{Uji Homogenitas}

Uji homogenitas digunakan untuk mengetahui apakah data dari hasil penelitian pada kelas eksperimen dan kelas kontrol mempunyai nilai varian yang sama atau tidak. Dikatakan mempunyai nilai varian yang sama/ tidak berbeda (homogen) apabila taraf signifikansinya yaitu $\geq 0.05$ dan jika taraf signifikansinya yaitu $<0.05$ maka data disimpulkan tidak mempunyai nilai varian yang sama/ berbeda (tidak homogen). Berikut ini hasil uji homogenitas.

Dari hasil perhitungan uji homogenitas pada diketahui bahwa nilai signifkansinya adalah 0.366. Karena nilai yang diperoleh dari uji homogenitas taraf signifikansinya $\geq 0.05$, maka data mempunyai nilai varian yang sama/ tidak berbeda (homogen). Jadi dapat disimpulkan dari perhitungan uji homogenitas bahwa kelas yang diberi 2 perlakuan yaitu kelas eksperimen (video) dan kelas kontrol (buku cerita) dapat mempengaruhi kemampuan berbicara anak usia 4-5 tahun. Selanjutnya akan dilakukan analisis data dengan uji Independent Sample T-test.

\section{Uji Independent Sample T-test}

Uji Independent Sample T-test ini untuk 
melihat ada atau tidak nya perbedaan dalam mengambil keputusan apakah hipotesis penelitian diterima atau ditolak, adapun hipotesis yang diuji adalah:

$\mathrm{H} 0=$ varian populasi identik/sama

$\mathrm{Ha}=$ varian populasi tidak identik/tidak sama

Dengan kriteria pengujiannya adalah sebagai berikut: Apabila nilai probabilitas $(p) \geq 0.05$ maka $\mathrm{HO}$ diterima. Apabila nilai probabilitas (p) $<0.05$ maka $H O$ ditolak. Berdasarkan hasil uji Independent Sample T-test pada bagian equal variances assumed diketahui nilai Sig. (2tailed) sebesar 0.000, menunjukkan bahwa $0.000<0.05$ maka $\mathrm{H}_{0}$ ditolak, artinya ada perbedaan yang signifikan antara hasil belajar kelas A dan Kelas B.

Selanjutnya akan dilakukan analisis pada baris equal variances assumted, dapat dilihat bahwa hasil t-test sebesar 8.126 dengan $\mathrm{df}=28$; perbedaan mean $=8.20$; perbedaan standard error $=1.00916 ;$ perbedaan post-test terendah $=$ 6.13282 dan tertinggi $=10.26718$.

Untuk mengetahui taraf signifikansi perbedaannya harus digunakan nilai ttabel atau tteoritik yang terdapat pada tabel nilai-nilai t. Karena nilai df sebesar 28, maka diperoleh nilai ttabel $=1.70113$ pada taraf signifikansi $5 \%$.

Dari nilai $t_{\text {tabel }}$ ini dapat dituliskan sebagai berikut; $t_{\text {tabel }}$ atau tteoritik dengan taraf signifikansi $5 \%=1.70113<$ thitung atau tempirik sebesar $=8.126$ untuk thitung atau tempirik hasil belajar. Hal itu juga ditunjukkan dengan nilai rata-rata (mean) pada kelas eksperimen (video) yaitu sebesar 30.2667 lebih besar jika dibandingkan dengan nilai rata-rata (mean) pada kelas kontrol (buku cerita) yaitu sebesar 22.0667.

Hasil analisis data yang dilakukan peneliti menunjukkan beberapa hal bahwa ada perbedaan hasil nilai rata-rata dari kelas eksperimen (video) dan kelas kontrol (buku cerita). Dapat dilihat bahwa nilai rata-rata (mean) kelas eksperimen (video) yaitu sebesar 30.2667 dan untuk kelas kontrol (buku cerita) sebesar 22.0667. Berdasarkan hasil uji normalitas dan uji homogenitas video pembelajaran telah memenuhi syarat bahwa video pembelajaran berpengaruh terhadap kemampuan berbicara anak dan dengan hasil uji
Independent Sample T-test menunjukkan bahwa ada perbedaan yang signifikan antara kelas eksperimen (video) dan kelas kontrol (buku cerita). Perbedaan juga terlihat dari hasil nilai per indikator, jumlah skor per indikator di kelas eksperimen (video) lebih tinggi dibandingkan jumlah skor per indikator di kelas kontrol (buku cerita).

Berdasarkan kemampuan indikator anak yang telah diteliti dari ketiga indikator tersebut kelas eksperimen lebih tinggi hasil skor per indikator nya dibandingkan kelas kontrol (buku cerita) karena video menyajikan suatu gambar hidup dan terdapat suara yang akan menarik perhatiannya dibandingkan dengan hanya mendengarkan gurunya bercerita dengan buku cerita. Sesuai dengan pendapat Kustandi dan Sutjipto (2011) menjelaskan bahwa video memiliki kemampuan melukiskan gambar hidup beserta suara yang memberikan daya tarik sendiri dengan menyajikan informasi, serta menjelaskan konsep yang akan mempengaruhi siswa sehingga siswa merasa seperti berada di suatu tempat yang sama dengan program yang ditayangkan video.

Apabila dianalisa pada indikator pertama yaitu mengulang kalimat sederhana pada kelas kontrol (buku cerita) melalui buku cerita yang membacakan kalimat tersebut hanya guru sedangkan di kelas eksperimen (video) anak dapat melihat gambar dan suara tokoh didalam video sehingga lebih menarik bagi anak. Pada poin selanjutnya pada indikator kedua yaitu menjawab pertanyaan sesuai pertanyaan dan indikator ketiga menceritakan kembali isi cerita kemampuan anak juga lebih tinggi di kelas eksperimen (video), dengan adanya video anak lebih mudah memahami cerita karena anak mendapatkan pesan dan informasi yang ada di dalam video melalui penglihatan dan pendengaran mereka.

Teori Edgar Dale tentang kerucut pengalaman ketika anak membaca apa yang anak ingat hanya $10 \%$ jika dengan mendengarkan yang diingat $20 \%$ tetapi jika anak dapat langsung melihat gambar, video/film dan melihat demonstrasi apa yang anak ingat mencapai 30\% sedangkan jika anak dapat terlibat langsung, bermain peran, dan melakukan simulasi maka akan lebih besar lagi kemampuan mengingatnya, sehingga anak bisa menjawab pertanyaan dan juga menjelaskan kembali isi 
cerita karena anak mengingat apa yang sudah mereka lihat.

Melalui video, anak juga mendapatkan berbagai informasi dan pesan dari apa yang anak lihat dan anak dengar maka akan lebih mudah bagi anak ketika diberikan pertanyaan oleh guru tentang cerita yang sudah ditonton sesuai dengan pendapat Asyhar (2011) menjelaskan video adalah suatu media yang digunakan dalam kegiatan pembelajaran dengan melibatkan pendengaran dan penglihatan sekaligus dalam satu proses atau kegiatan, pesan dan informasi dapat disalurkan melalui media ini baik verbal/non verbal yang mengandalkan baik pendengaran dan penglihatan. Asyhar menjelaskan bahwa pesan dan informasi yang anak dapatkan dari video mereka dapatkan melalui yang anak dengar dan anak lihat langsung dari video. Media video digunakan dalam pembelajaran di kelas dalam kelompok besar, hal ini selaras dengan pendapat Nugent dalam Smaldino (2008), video merupakan media yang cocok untuk berbagai macam pembelajaran, seperti kelas, kelompok kecil, bahkan satu siswa sekalipun.

\section{SIMPULAN DAN SARAN}

Berdasarkan hasil analisis dan pembahasan tentang "Pengaruh Video Pembelajaran Cerita dan Lagu terhadap Kemampuan Berbicara Anak Usia 4-5 Tahun di PAUD Harmoni, dapat diambil kesimpulan bahwa: "Terdapat pengaruh video pembelajaran cerita dan lagu terhadap kemampuan berbicara anak usia 4-5 tahun". Ditunjukan dengan hasil uji normalitas bahwa data tersebut berdistribusi normal. Data tersebut diperoleh dengan nilai $\mathrm{Z}$ yaitu 0.553 dan Asymp.Sign sebesar 0.920. Kemudian ditunjukan juga dengan hasil uji homogentitas bahwa data tersebut nilai signifkansinya adalah 0,366 maka data mempunyai nilai varian yang sama/ tidak berbeda (homogen). Sedangkan dengan Uji Independent Sample Ttest dengan nilai Sig. (2-tailed) sebesar 0.000, menunjukkan bahwa 0.000 lebih kecil dari taraf signifikansi, artinya ada perbedaan yang signifikan antara hasil belajar kelas A (kelas eskperimen) yang diberikan video pembelajaran dan kelas B (kelas kontrol) yang hanya diberikan buku cerita.

Berdasarkan hasil penelitian dan kesimpulan yang telah diuraikan di atas, maka dapat diberikan beberapa saran guru hendaknya menggunakan video pembelajaran untuk meningkatkan kemampuan berbicara pada anak, guru dapat mencari video melalui youtube yang sesuai dengan kebutuhan atau guru dapat membuat video yang menarik. Apabila sekolah memiliki ruangan kosong sebaiknya memanfaatkan ruangan tersebut sebagai ruang Auditory and Visual dengan menyediakan berbagai macam video pembelajaran dan penelitian ini dapat dijadikan sebagai referensi untuk melakukan penelitian terkait dengan perkembangan bahasa pada kemampuan bahasa yang lain menggunakan video pembelajaran.

\section{DAFTAR PUSTAKA}

Akhadiah, S., dkk. (2012). Pembinaan kemampuan menulis bahasa indonesia. Jakarta: Erlangga.

Ashyar, R. (2011). Kreatif mengembangkan media pembelajaran. Jakarta: Gaung Persada Press.

Darwanto. (2007). Televisi sebagai media pendidikan. Yogyakarta: Pustaka Pelajar.

Daryanto. (2010). Media pembelajaran . Yogyakarta: Gava Media .

Gunarti, W., dkk. (2008). Metode pengembangan perilaku dan kemampuan dasar anak usia dini. Jakarta: Universitas Terbuka.

Kustandi, C., Sutjipto, B. (2011). Mendia pembelajaran: manual dan digital. Bogor: Ghalia Indonesia.

Morrison, G. S. (2012). Dasar-dasar pendidikan anak usia dini. Jakarta: Indeks.

Nurgiyantoro, B. (2010). Penilaian pembelajaran bahasa. Yogyakarta: BPFE.

Peraturan Menteri RI Nomor 137 Tahun 2013 Tentang Standar Nasional Pendidikan.

Prastowo, A. (2011). In panduan kreatif membuat bahan ajar inovatif. Jogjakarta: Diva Press.

Sadiman, A.S., dkk. (2011). Media pendidikan, pengertian, pengembangan, dan pemanfaatannya. Jakarta: Raja Grafindo Persada.

Smaldino, S.E., dkk. (2008). Instructional technology and media for learning (ninth edition). NJ: Pearson Education Inc.

Sugiyono. (2018). Metode penelitian pendidikan pendekatan kuantitatif, kualitatif, dan $R \& D$. Bandung: Alfabeta. 
Suhartono. (2005). Pengembangan keterampilan bicara anak usia dini. Jakarta: Departemen Pendidikan Nasional.

Sujiono, Y. N. (2013). Konsep dasar pendidikan anak usia dini. Jakarta: PT Indeks.

Undang-Undang Dasar 1945 Pasal 31 Ayat 1. 2014. Jakarta: diperbanyak oleh CV Sinar Grafika.
Undang-Undang Nomor 20 Tahun 2003 tentang sistem pendidikan nasional. Jakarta: CV. Sinar Grafika.

Undang-Undang Republik Indonesia Nomor 23 Tahun 2002 tentang perlindungan anak.

Usman, Basyiruddin. (2002). Media Pendidikan. Jakarta: Ciputat Press.

Yusuf, S. (2000). Psikologi perkembangan anak dan remaja. Bandung: Rosda Karya.

http://aldosamosir.files.wordpress.com//yah oo.com Diakses tanggal 20 Juli 2019 